Article

\title{
Induced Spawning of F1 Wreckfish (Hāpuku) Polyprion oxygeneios Using a Synthetic Agonist of Gonadotropin-Releasing Hormone
}

\author{
Matthew J. Wylie ${ }^{1, *}+{ }^{(D)}$, Alvin N. Setiawan ${ }^{2}$, Glen W. Irvine ${ }^{2}$, Abigail Elizur ${ }^{3}(\mathbb{D}$, \\ Yonathan Zohar ${ }^{4}$, Jane E. Symonds ${ }^{2, \ddagger}$ and P. Mark Lokman ${ }^{1}$ \\ 1 Department of Zoology, University of Otago, PO Box 56, Dunedin 9054, New Zealand \\ 2 National Institute of Water and Atmospheric Research, Northland Marine Research Centre, \\ PO Box 147, Ruakaka 0151, New Zealand \\ 3 GeneCology Research Centre, University of the Sunshine Coast, Queensland 4556, Australia \\ 4 Department of Marine Biotechnology and Institute of Marine and Environmental Technology, \\ University of Maryland, Baltimore County, Baltimore, MD 21202, USA \\ * Correspondence: Matthew.Wylie@plantandfood.co.nz; Tel.: +64-3-989-7644 \\ + Present address: The New Zealand Institute for Plant and Food Research, Seafood Production Unit, \\ 293-297 Port Nelson, Nelson 7010, New Zealand. \\ $\ddagger \quad$ Present address: Cawthron Institute, Private Bag 2, Nelson 7042, New Zealand.
}

Received: 17 March 2019; Accepted: 1 July 2019; Published: 8 July 2019

\begin{abstract}
Wild-caught hāpuku (Polyprion oxygeneios) spawn readily in captivity, but although first filial (F1) hāpuku complete vitellogenesis, females fail to undergo oocyte maturation and spawn or produce poor quality eggs. This study investigated whether administration of a synthetic agonist of gonadotropin-releasing hormone (GnRHa) could improve F1 hāpuku spawning and complete the life-cycle in captivity. Spawning trials were conducted over 2 years in 2013 and 2014, when F1 were aged five and six years. In 2013, females previously conditioned under a variable or constant temperature regime were implanted with GnRHa $\left(100 \mu \mathrm{g} / \mathrm{kg}^{-1}\right)$ or blank implants constructed of powdered cellulose and cholesterol. Spawning was erratic and egg quality very poor in all tanks. No F2 offspring were produced by communal spawning. In contrast, viable F2 larvae were produced by strip-spawning and in vitro fertilization after a series of GnRHa injections. In 2014, two additional trials were conducted: females received ethylene-vinyl acetate copolymer (EVAc) matrix implants containing GnRHa $\left(100 \mu \mathrm{g} / \mathrm{kg}^{-1}\right)$ or blank implants and in the second trial, two GnRHa doses $\left(100 \mu \mathrm{g} / \mathrm{kg}^{-1}\right.$ and $\left.50 \mu \mathrm{g} / \mathrm{kg}^{-1}\right)$ were tested. Eggs were first detected in all tanks $12-17$ days post-implantation when females received $100 \mu \mathrm{g} / \mathrm{kg}^{-1} \mathrm{GnRHa}$ implants, but not in the lower dose or control tanks. In summary, this study achieved induction of female spawning with GnRHa implants (target dose $100 \mu \mathrm{g} / \mathrm{kg}^{-1}$ ) and the successful production of F2 hāpuku in captivity by strip-spawning.
\end{abstract}

Keywords: Polyprion; spawning induction; oocyte maturation; aquaculture; ovulation; GnRHa; gonadotropin; wreckfish; broodstock; hāpuku

\section{Introduction}

Closing or 'completing' the life-cycle of a species in captivity is particularly important for the development of intensive aquaculture as it overcomes the need to capture seed from the wild and enables the breeding of selected individuals with desirable performance characteristics [1-3]. Of equal importance is the ability to induce spawning of broodstock to produce large numbers of high quality seed on demand [4]. 
Although issues surrounding acquisition of milt in male fish should not be overlooked (i.e., quality and/or quantity), reproductive dysfunctions are usually more common in female fish, especially the failure of broodstock to undergo oocyte maturation, ovulation and spawning $[5,6]$. This aquaculture bottleneck often results from a dysfunction in the release of luteinizing hormone (Lh) from the pituitary gland after vitellogenesis has been completed [5,7]. The brain releases gonadotropin-releasing hormone $(\mathrm{GnRH})$ upon the detection of appropriate exogenous cues (e.g., water temperature, photoperiod, lunar cycle or behavioral stimuli). However, these cues are often suboptimal or altogether lacking in captivity and reproductive events can be compromised further by stress imposed by human activities under culture conditions [8,9]. Under circumstances when GnRH release does occur, a cascade of endocrine events (e.g., gonadotropin secretion, the synthesis of maturational hormones and oocyte maturation) is initiated which ultimately facilitates the spawning of viable gametes [4-6,10-12].

The development and use of synthetic agonists of gonadotropin-releasing hormone (GnRHa) have proven useful to mitigate reproductive dysfunctions in multiple cultured species. Examples include Atlantic bluefin tuna (Thunnus thynnus) [13], longfin yellowtail (Seriola rivoliana) [14], meagre (Argyrosomus regius) [15], blue mackerel (Scomber australasicus) and Eastern little tuna (Euthynnus affinis) [16].

Exogenous GnRHa is often administered in a liquid form via intramuscular (IM) injections. Alternatively, GnRHa can be incorporated into sustained-release delivery systems (hereafter referred to as implants). Implants are frequently constructed of a cellulose-cholesterol matrix [17,18], an ethylene-vinyl acetate copolymer (EVAc) matrix [13], biodegradable microspheres [19] or a matrix of cholesterol and cocoa butter [20], which too can be administered by IM injection [5]. Under appropriate conditions, the GnRHa mimics the actions of the native GnRH peptide and acts at the level of the pituitary to induce Lh secretion and the downstream cascade of events described above.

An advantage of GnRHa implants is their ability to promote long-term secretion of Lh as described in striped bass (Morone saxatilis) [21] and European seabass (Dicentrarchus labrax) [19]. The administration of implants also enables flexibility in the timing of hormone administration on occasions when females may not have fully completed vitellogenesis $[5,6]$. Furthermore, the sustained-release nature of implants can minimize the need for multiple broodstock handling events that are often required for serial IM GnRHa injections. This can be stressful and impractical, particularly when working with large broodstock [5].

Beginning in 2002, New Zealand's National Institute of Water and Atmospheric Research (NIWA) established a breeding program for the wreckfish (Polyprion oxygeneios), locally known as 'hāpuku' [22]. NIWA's primary source of hāpuku eggs has been from wild-caught captivity-acclimated (F0) broodstock, which predictably spawn large quantities of eggs (70-80\% fertilization rate) from late August through to December without any hormonal intervention [22]. However, despite first filial (F1) hāpuku completing vitellogenesis when maintained under similar environmental conditions to their parents [23], females have exhibited reproductive dysfunctions, including the complete failure to spawn or the production of poor quality eggs in low quantities, at least within the first six years of life. Lack of spawning may be due to (a) failure of post-vitellogenic oocytes to undergo maturation and ovulation or (b) failure to spawn eggs that are ovulated.

Accordingly, this study aimed to investigate whether hormonal manipulations with GnRHa could improve F1 hāpuku spawning to allow, for the first time, the production of F2 offspring and complete-cycle culture of this species in captivity.

\section{Results}

\subsection{Trial: Collection of Gametes for Strip-Spawning and In Vitro Fertilization}

Strip-spawning required the fish to be handled and two females failed to recover from anesthesia: one blank-treated female from the constant temperature (CT) photo-thermal regime group (first injection) and one GnRHa-treated female from the varying temperature (VT) photo-thermal regime group (second injection). At the time of the first IM GnRHa injection, mean oocyte diameter ranged between 
0.9 and $1.7 \mathrm{~mm}$ (Table 1). Twenty-four hours later, ovulation was not evident among saline controls. However, four GnRHa-treated females (one from the CT group, three from the VT group) produced free-flowing ovulated eggs of varying volumes (Table 1). One GnRHa-treated female from the VT group (Female B) produced transparent free-flowing ovulated eggs $\left(93 \mathrm{~mL} ; 1430 \mathrm{eggs} \mathrm{kg}^{-1}\right.$ ) at strip-spawning (Figure 1c); these eggs had dramatically increased in size, from an average of $1.2 \mathrm{~mm}$ at the time of the first GnRHa injection, to $1.8 \mathrm{~mm}$ at stripping, $24 \mathrm{~h}$ later (Table 1). In contrast, only small volumes (18-34 mL; 224-488 eggs kg ${ }^{-1}$ ) of cloudy ovulated eggs were collected from the three other females (Females A, D, J), and these eggs did not show any hydration-associated increase in diameter (Table 1). Ovulated eggs from Female B were fertilized in vitro by pooled milt from two males, yielding a fertilization rate of $84 \%$. Fertilization of the cloudy eggs retrieved from the three other females predictably failed.

Twenty-four hours later (at $48 \mathrm{~h})$, a further $130 \mathrm{~mL}\left(2000 \mathrm{eggs} \mathrm{kg}^{-1}\right)$ of ovulated eggs was obtained by stripping Female B, but the eggs were cloudy (Figure 1d) and fertilization failed. No other eggs were obtained at this time or at $72 \mathrm{~h}$ from the remaining females. However, at $96 \mathrm{~h}$, eggs were detected in the VT tank with egg production continuing for several weeks (data not shown). Fertilization (1\%) was detected in only one batch of these communally spawned eggs (total volume $110 \mathrm{~mL}\left(1562 \mathrm{eggs} \mathrm{kg}^{-1}\right)$; floating volume $30 \mathrm{~mL}\left(410\right.$ eggs kg$\left.\left.^{-1}\right)\right)$, but embryos failed to develop beyond the gastrula stage.

Embryonic development of surviving F2 was documented from eggs fertilized in vitro (Figure 2). During egg incubation, oil globules were a dark amber color. The most rapid changes in embryonic development were observed shortly after fertilization. At an incubation temperature of $13.5 \pm 1{ }^{\circ} \mathrm{C}$, the two-cell stage was evident at $\sim 3.5 \mathrm{~h}$ post-fertilization. Zygotes reached the 16-cell stage at $\sim 6.5 \mathrm{~h}$ and larvae hatched at 5-6 days post-fertilization. Embryo development was consistent with that previously described for hāpuku [24] and the survival rate of F2 offspring ( 12,000 eggs) was $1.4 \%$ at 28 days post-hatching. While no F2 were produced during communal spawning events when blankand GnRHa-implanted individuals were co-housed (data not shown), surviving F2 from eggs fertilized in vitro were successfully raised to sub-adults using grow-out conditions as previously reported [22,25].
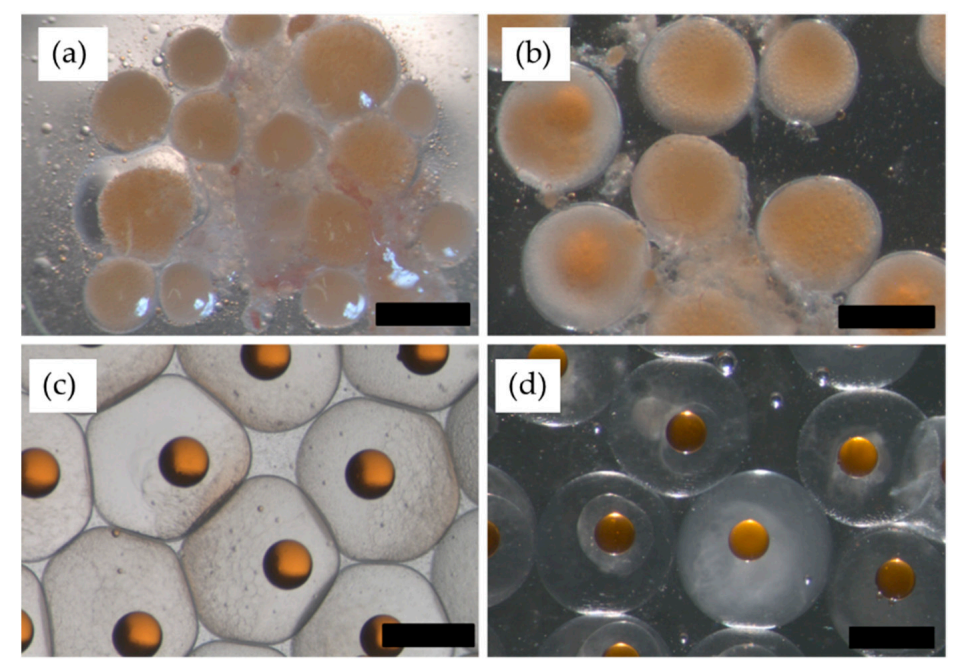

Figure 1. Progression of ovarian development in a first filial (F1) hāpuku (Polyprion oxygeneios) administered a $1 \mathrm{mg}$ GnRHa implant in October 2013 (target dose of $100 \mu \mathrm{g} / \mathrm{kg}^{-1}$ of body weight; achieved dose $118 \mu \mathrm{g} / \mathrm{kg}^{-1}$ ), followed three weeks later by two consecutive intramuscular injections of GnRHa (dose: $30 \mu \mathrm{g} / \mathrm{kg}^{-1}$ ) $24 \mathrm{~h}$ apart. (a) Ovarian biopsy containing late vitellogenic oocytes (mean dimeter $\geq 0.9 \mathrm{~mm}$ ) collected 21 October 2013 prior to administration of a $1 \mathrm{mg}$ GnRHa implant; (b) an ovarian biopsy collected 11 November 2013 prior to first GnRHa injection with lipid droplet coalescence becoming apparent when developing oocytes reached $\sim 1.2-1.3 \mathrm{~mm}$ in diameter; (c) fertilizable ovulated eggs obtained 12 November 2013 by strip-spawning ( $24 \mathrm{~h}$ post the first GnRHa injection); (d) overripe ovulated eggs (unfertilizable) obtained 13 November 2013 by strip-spawning 48 h post the first GnRHa injection. Scale bar $=1 \mathrm{~mm}$. 
Table 1. Summary of the number of first filial (F1) hāpuku (Polyprion oxygeneios) in each temperature group and the IM injection treatments of fish subjected to strip-spawning during the 2013 spawning season. Gonadotropin-releasing hormone (GnRHa) pre-treated females from both temperature groups received two IM injections of GnRHa (dose: $30 \mu \mathrm{g} / \mathrm{kg}^{-1}$ ) $24 \mathrm{~h}$ apart and blank pre-treated females were given two IM injections of saline $24 \mathrm{~h}$ apart. All fish were assessed for ovulation by stripping at $24 \mathrm{~h}$ intervals over a $72 \mathrm{~h}$. Details of the varying temperature (VT) and constant temperature (CT) photo-thermal regimes are as described in the text. One liter of eggs equates to $\sim 130,000$ eggs.

\begin{tabular}{|c|c|c|c|c|c|c|c|c|}
\hline \multirow{2}{*}{ Temp Group } & \multirow{2}{*}{ q } & \multirow{2}{*}{$\begin{array}{c}\text { Body Weight } \\
\text { (kg) }\end{array}$} & \multirow{2}{*}{$\begin{array}{l}\text { GnRHa Dose } \\
\left(\mu \mathrm{g} / \mathrm{kg}^{-1}\right) \times 2\end{array}$} & \multicolumn{2}{|c|}{$\begin{array}{c}\text { First Injection (Time Zero) Date: } \\
11 \text { November } 2013\end{array}$} & \multicolumn{2}{|c|}{$\begin{array}{l}\text { Second Injection ( } 24 \text { h Post-First } \\
\text { Injection) Date: } 12 \text { November } 2013\end{array}$} & \multirow{2}{*}{$\begin{array}{c}\text { Fertilization } \\
\text { Rate (\%) }\end{array}$} \\
\hline & & & & Mean OD (mm) & $\begin{array}{l}\text { Ovulated Egg } \\
\text { Volume (mL) }\end{array}$ & Mean OD (mm) & $\begin{array}{l}\text { Ovulated Egg } \\
\text { Volume (mL) }\end{array}$ & \\
\hline VT & $\mathrm{A}$ & 9.06 & 30 & 1.24 & 0 & 1.25 & 34 & 0 \\
\hline VT & $\mathrm{B}$ & 8.45 & 30 & 1.24 & 0 & 1.85 & 93 & 84 \\
\hline VT & $\mathrm{C}$ & 10.12 & 30 & 1.20 & 0 & 1.20 & 0 & - \\
\hline VT & $\mathrm{D}$ & 10.43 & 30 & 1.29 & 0 & 1.22 & 18 & 0 \\
\hline $\mathrm{CT}$ & $\mathrm{I}$ & 7.86 & 30 & 1.2 & 0 & 1.13 & 0 & - \\
\hline $\mathrm{CT}$ & $\mathrm{J}$ & 5.80 & 30 & No biopsy & 0 & 1.06 & 24 & 0 \\
\hline $\mathrm{CT}$ & $\mathrm{K}$ & 6.76 & 30 & 1.07 & 0 & No biopsy & 0 & - \\
\hline VT & $\mathrm{E}$ & 7.28 & 0 & 1.30 & 0 & 1.24 & 0 & - \\
\hline VT & $\mathrm{F}$ & 9.58 & 0 & 0.94 & 0 & 1.07 & 0 & - \\
\hline VT & G & 10.83 & 0 & 1.16 & 0 & 1.08 & 0 & - \\
\hline VT & $\mathrm{H}$ & 8.35 & 0 & 1.13 & 0 & 1.09 & 0 & - \\
\hline $\mathrm{CT}$ & $\mathrm{L}$ & 7.05 & 0 & 1.07 & 0 & 1.07 & 0 & - \\
\hline $\mathrm{CT}$ & $\mathrm{M}$ & 9.55 & 0 & 0.94 & 0 & No biopsy & (female died) & - \\
\hline
\end{tabular}



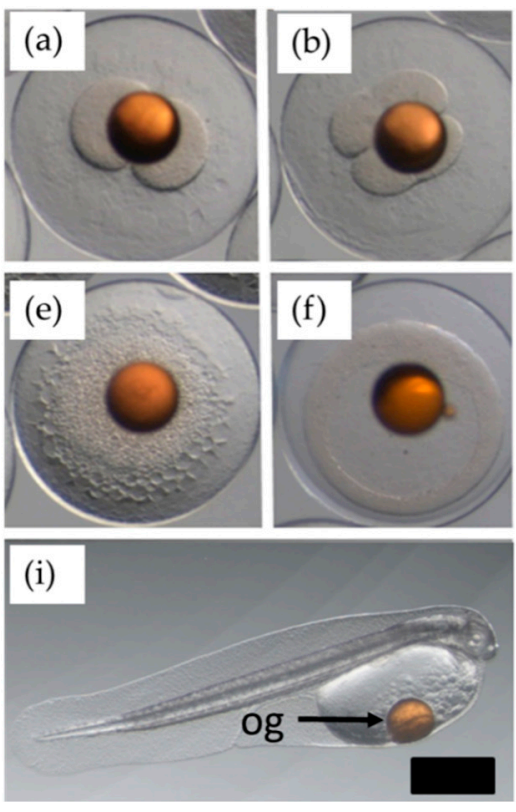
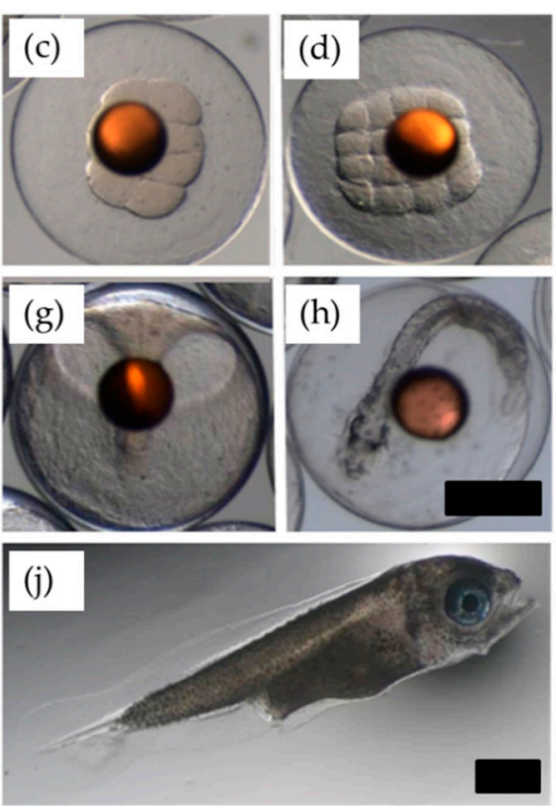

Figure 2. Development of second filial generation (F2) hāpuku (Polyprion oxygeneios) incubated at $13.5{ }^{\circ} \mathrm{C}$. Gametes were collected by strip-spawning and fertilized in vitro. (a) Two-cell stage ( $\sim 3.5 \mathrm{~h}$ post-fertilization); (b) four-cell stage ( 4.5 h post-fertilization); (c) eight-cell stage ( $\sim 5.5 \mathrm{~h}$ post-fertilization); (d) 16-cell stage ( $\sim 6.5 \mathrm{~h}$ post-fertilization); (e) blastula ( $\sim 14 \mathrm{~h}$ post-fertilization); (f) gastrula (36 h post-fertilization); (g) neurula (51 h post-fertilization); (h) tail-free embryo (108 h post-fertilization); (i) 2 day old larva; (j) 20 day old larva. Scale bar $=1 \mathrm{~mm}$. Abbreviations: og $=$ oil globule.

\subsection{Trial 2A: Effect of GnRHa Administration Using EVAc Implants}

Ovulated eggs were detected in all three GnRHa-treated tanks from 12 to 15 days until almost 90 days post-implantation, when the study was ended (Figure 3). In contrast, no ovulated eggs were detected for 30 days in tanks housing blank-implanted fish, at which time they were also implanted as part of Trial 2B (Section 2.3 below). The largest total volume of eggs collected from a single tank with GnRHa-treated fish in one day was $900 \mathrm{~mL}\left(11,470 \mathrm{eggs} \mathrm{kg}^{-1}\right)$. Among a total of 123 spawns, $20 \%$ of the spawned batches contained fertilized eggs (fertilized spawn rate). The fertilization rate of each spawn was highly variable (0-98\%), as was the proportion of floating eggs (0-85\%) (Figure 3). Embryonic development was successful in three spawns with hatch rates varying between $60 \%$ and $87 \%$. Unfortunately, no larvae survived beyond 25 days post-hatching $(\mathrm{dph})$, with peak mortalities occurring at 15-18 dph.

Due to the low number of viable eggs produced, eggs from only eight out of 25 fertilized spawns were submitted for parentage analysis and successfully genotyped. Results indicated that at least seven females ( $33 \%$ of all females) and five males ( $26 \%$ of all males) were contributing to the communal spawning events across the three GnRHa-treated tanks where fertilization was detected (Table 2; Tanks 1-3). A posteriori genotyping showed that prior to GnRHa administration (dose range: $88-131 \mu \mathrm{g} / \mathrm{kg}^{-1}$ ), mean oocyte diameters of 'contributing' females ranged between 0.9 and $1.2 \mathrm{~mm}$. The achieved GnRHa dose of males contributing to successful spawning events ranged between 51 and $62 \mu \mathrm{g} / \mathrm{kg}^{-1}$. 

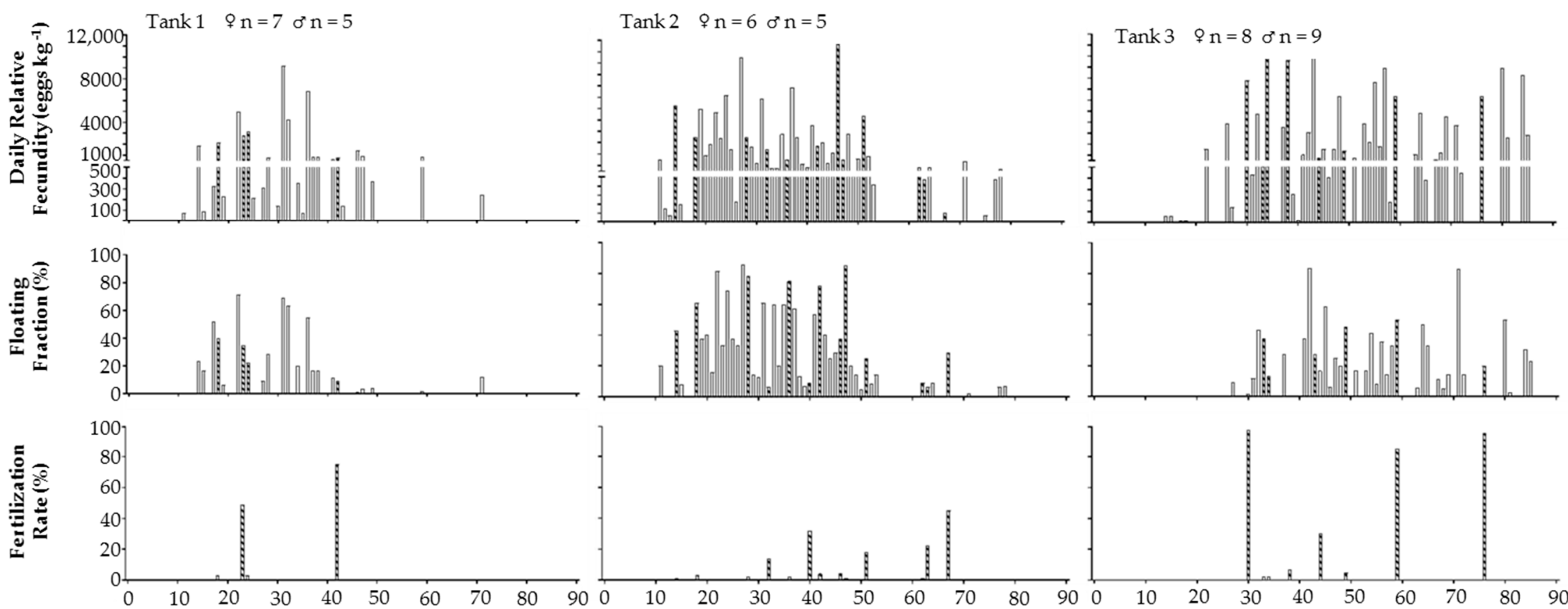

Days post-implantation

Figure 3. Trial 2A, GnRHa-treated tanks only: Spawning performance of first filial (F1) hāpuku (Polyprion oxygeneios) maintained on an annually cycling thermal regime that varied from cool temperatures in the winter months $\left(10.0-12.5^{\circ} \mathrm{C}\right)$ to warmer temperatures $\left(17^{\circ} \mathrm{C}\right)$ in the summer months prior to being held at $13.5^{\circ} \mathrm{C}$ for the spawning season. Each tank contained GnRHa implanted females $\left(n=21\right.$ distributed amongst three tanks; target dose of $100 \mu \mathrm{g} / \mathrm{kg}^{-1}$; achieved dose $\left.79-139 \mu \mathrm{g} / \mathrm{kg}^{-1}\right)$ and males ( $n=19$ distributed amongst three tanks; target dose of $50 \mu \mathrm{g} / \mathrm{kg}^{-1}$; achieved dose $49-76 \mu \mathrm{g} / \mathrm{kg}^{-1}$ ). The number of fish in each tank is shown on the figures. Data are shown as estimates of daily relative fecundity (number of eggs produced per $\mathrm{kg}^{-1}$ of mean body weight of the females in each tank), the percentage of floating eggs and the percentage of fertilized eggs from each spawning event. Striped and blank bars represent batches of eggs where fertilization was detected or absent, respectively. Blank-implanted fish were housed separately ( $n=3$ tanks) from GnRHa-implanted fish. No eggs were detected from blank-treated fish. 
Table 2. Parentage analysis of fertilized eggs obtained from communal spawning events by first filial (F1) hāpuku (Polyprion oxygeneios) during the 2014 spawning season (Trials 2A and 2B). The number of eggs genotyped from each batch was 20 with the exception of one batch (Tank 1 ) where 11 eggs were genotyped.

\begin{tabular}{|c|c|c|c|c|c|c|c|c|}
\hline Trial & Tank & $\begin{array}{c}\text { Target } \\
\text { GnRHa Dose } \\
\left(\mu \mathrm{g} / \mathrm{kg}^{-1}\right)\end{array}$ & $\begin{array}{l}\text { Spawning } \\
\text { (Yes/No) }\end{array}$ & $\begin{array}{c}\text { No. } \\
\text { Batches } \\
\text { Genotyped }\end{array}$ & $\begin{array}{l}\text { Total No. } \\
\text { Females } \\
\text { in Tank }\end{array}$ & $\begin{array}{l}\text { No. Females } \\
\text { Detected by } \\
\text { Genotyping }\end{array}$ & $\begin{array}{c}\text { Total No. } \\
\text { Males in } \\
\text { Tank }\end{array}$ & $\begin{array}{l}\text { No. Males } \\
\text { Detected by } \\
\text { Genotyping }\end{array}$ \\
\hline \multirow{6}{*}{ Trial $2 A$} & Tank 1 & 100 & Yes & 1 & 7 & 1 & 5 & 1 \\
\hline & Tank 2 & 100 & Yes & 5 & 6 & 3 & 5 & 1 \\
\hline & Tank 3 & 100 & Yes & 2 & 8 & 3 & 9 & 3 \\
\hline & Tank 4 & 0 & No & - & 6 & - & 4 & - \\
\hline & Tank 5 & 0 & No & - & 4 & - & 11 & - \\
\hline & Tank 6 & 0 & No & - & 8 & - & 8 & - \\
\hline \multirow{2}{*}{ Trial $2 B$} & Tank 7 & 100 & Yes & 9 & 5 & 3 & 9 & 5 \\
\hline & Tank 8 & 50 & No & - & 5 & - & 9 & - \\
\hline
\end{tabular}

\subsection{Trial 2B: Effect of Different GnRHa Doses on Communal Spawning}

Spawning occurred in the high dose GnRHa group from 17 days post-implantation onwards, with a fertilized spawn rate of $70 \%$ among 17 spawned batches (Figure 4). Eggs were detected almost daily until approximately 50 days post-implantation. Maximum fertilization rate was $98 \%$, but floating fractions were usually $\leq 50 \%$ of the total volume of eggs collected (Figure 4). No larvae survived beyond $6 \mathrm{dph}$. In contrast, no eggs were detected from the group implanted with the low dose of GnRHa.
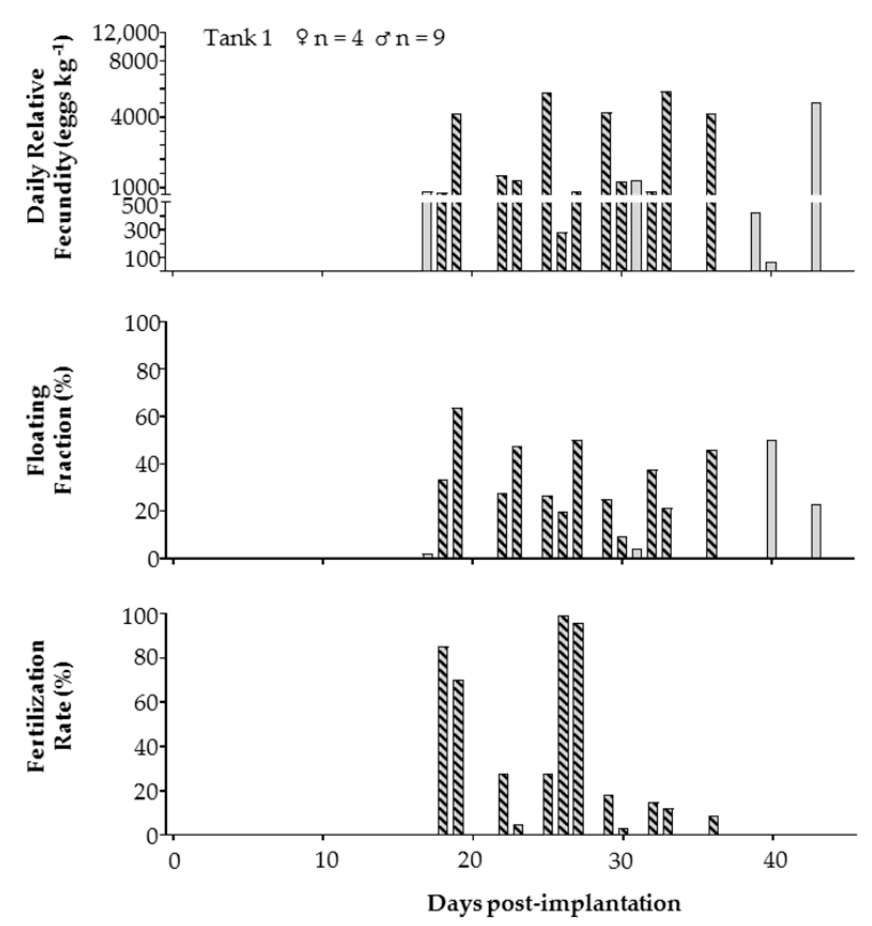

Figure 4. Trial 2B, high dose tank only: Spawning performance of first filial (F1) hāpuku (Polyprion oxygeneios) maintained on an annually cycling regime from cool temperatures in the winter months $\left(10.0-12.5^{\circ} \mathrm{C}\right)$ to warmer temperatures $\left(17^{\circ} \mathrm{C}\right)$ in the summer months prior to being held at $13.5^{\circ} \mathrm{C}$ for the spawning season. Females were administered $1 \mathrm{mg}$ GnRHa implants (high dose) $\left(n=5\right.$; target dose of $100 \mu \mathrm{g} / \mathrm{kg}^{-1}$; achieved dose $\left.95-145 \mu \mathrm{g} / \mathrm{kg}^{-1}\right)$ and males were administered implants containing a dose of $0.5 \mathrm{mg} \mathrm{GnRHa}(n=9$; target dose of $50 \mu \mathrm{g} / \mathrm{kg}^{-1}$; achieved dose $38-53 \mu \mathrm{g} / \mathrm{kg}^{-1}$ ). Data are shown as estimates of daily relative fecundity (number of eggs produced per $\mathrm{kg}^{-1}$ of mean body weight of the females in each tank), the percentage of floating eggs and the percentage of fertilized eggs from each spawning event. Striped and blank bars represent batches of eggs where fertilization was detected or absent, respectively. No eggs were detected from the tank containing low-dose treated fish. 
Nine batches of fertilized eggs out of a total of 12 were submitted for parentage analysis and successfully genotyped. Genotyping showed that at least $60 \%$ of females $(n=5)$ and $55 \%$ of males $(n=9)$ contributed to the fertilized eggs at some stage during Trial 2B (Table 2; Tank 7). Using a posteriori genotyping information, mean oocyte diameters $(1.1-1.2 \mathrm{~mm})$ prior to hormonal administration of 'contributing' females were within the range of those from contributing females identified in Trial 2A. GnRHa doses in contributing females from Trial 2B ranged from 102 to $145 \mu \mathrm{g} / \mathrm{kg}^{-1}$, while achieved GnRHa doses of males contributing to successful spawning events ranged between 47 and $85 \mu \mathrm{g} / \mathrm{kg}^{-1}$.

\section{Discussion}

Despite being maintained under similar environmental conditions to their parents and completing vitellogenesis in captivity [23], F1 hāpuku up to six years old exhibited various reproductive dysfunctions. These dysfunctions include the complete failure to spawn naturally and the production of poor quality gametes in low quantities. The lack of spawning may be due to (a) failure of post-vitellogenic oocytes to undergo maturation and ovulation or (b) failure to spawn eggs that are ovulated. To understand and overcome this bottleneck, maturing F1 were subjected to GnRHa treatments during the 2013 and 2014 spawning seasons. Although there was notable variability in responses between individuals, tanks and years, this study successfully achieved two key aims: induction of spawning with GnRHa implants and closing of the life-cycle of hāpuku.

GnRHa implantation of females at a target dose of $100 \mu \mathrm{g} / \mathrm{kg}^{-1}$ promoted ovulation in $\mathrm{F} 1$ hāpuku and males implanted with a target dose of $50 \mu \mathrm{g} / \mathrm{kg}^{-1}$ successfully fertilized eggs. In 2014, the GnRHa-treated and control F1 were reared separately and only GnRHa-treated fish produced eggs from 12 to 15 days post-implantation. Furthermore, the dose-response trial showed that GnRHa was only effective at inducing ovulation at the higher dose (target dose $100 \mu \mathrm{g} / \mathrm{kg}^{-1}$ ) 17 days post-implantation. We also demonstrated that F2 hāpuku larvae from good quality strip-spawned eggs in 2013 were able to develop into normal juveniles with a survival rate that was comparable to that of F1 hāpuku juveniles.

Since spawning was evident only after GnRHa administration, F1 hāpuku may suffer from a dysfunction in the release of Lh from the pituitary gland at the end of vitellogenesis. The dysfunctional release of Lh is a common issue exhibited by many finfish species under aquaculture conditions $[5,6,9]$ and its release is a requisite for the initiation of oocyte maturation, ovulation and spawning [26]. Hence, F1 hāpuku at this age may be (a) synthesizing and storing Lh but not releasing it into the bloodstream, or (b) releasing Lh into the bloodstream but at insufficient quantities to accomplish oocyte maturation and spawning, as demonstrated in gilthead sea bream (Sparus aurata) [27].

It remains unclear what key factors or cues are preventing natural oocyte maturation, ovulation and spawning in F1 hāpuku. Such factors are particularly difficult to pinpoint and test experimentally due to the logistical complications and costs associated with rearing and handling large valuable broodstock, and the fact that reproductive performance depends on a multitude of factors. While the optimal photo-thermal regimes to maintain and spawn hāpuku are still under investigation, communal spawning of F0 hāpuku maintained between minimum temperatures of $10-12.5^{\circ} \mathrm{C}$ and maximum temperatures no greater than $18{ }^{\circ} \mathrm{C}$ yield relatively high fertilization rates $(70-80 \%)$ without the need for hormonal intervention [22]. This observation is interesting as one might expect the opposite: that wild-caught broodstock acclimated to foreign and confined captive conditions would require hormonal intervention to achieve spawning $[4,5]$ rather than F1 offspring that have been produced and raised under these conditions. However, in keeping with that observed in F1 hāpuku from our study, reproductive dysfunctions have been reported in F1 Senegalese sole (Solea senegalensis) [28].

There may be intrinsic biological constraints that are contributing to the poor reproductive success of hāpuku. For example, F1 reached sexual maturity at five years of age in captivity [23], while age estimates for sexual maturation in wild stocks in New Zealand range between 10 and 13 years [29]. Therefore, reproductive dysfunctions in F1 may be age-related and reflect the incompetency of the Brain-Pituitary-Gonad axis (e.g., the synthesis and release of relevant GnRH) as described in wild and 
captive striped bass [30]. Discrepancies in reproductive performance between age groups of broodstock have been observed in female Murray cod (Maccullochella peelii peelii) subjected to induced spawning with human chorionic gonadotropin (hCG) at two and three years of age to compare egg fertility [31]. Ovulation was successfully induced in every Murray cod from each year. However, oocyte diameters prior to hCG administration, post-fertilization viability and hatchability were substantially reduced in younger females [31].

The inability to detect chemical signals such as sex pheromones (e.g., via sensory neurons and olfactory apparatus) necessary for spawning [32] may also limit reproductive performance in young F1 hāpuku. For example, the inability to fully detect chemical signals may adversely affect reproductive behaviors such as courtship or other appropriate behavioral responses to achieve oocyte maturation and synchronized release and fertilization of eggs [33-35]. The importance of such chemical cues or socio-sexual stimuli on the later stages of reproduction have been demonstrated in gilthead seabream [36] and honeycomb grouper (Epinephelus merra) [37].

Spawning may also improve with age, ameliorating the severity of the reproductive dysfunction exhibited by F1 hāpuku. Although such sexual behaviors in fish are presumed to be innate rather than learned [33], studies on Siamese fighting fish (Betta splendens) have shown that younger sexually naive pairs have poorer synchronization of sexual and social interactions "bouts" than sexually experienced pairs [38]. Hence, a measure to promote and/or improve spawning behavior in hāpuku may be to combine wild-caught spawning-experienced and captive spawning-naive F1 individuals. In Senegalese sole, broodstock combinations of wild-caught and captive-bred fish have been useful for the identification of behavioral dysfunctions in captive-bred males. Accordingly, F1 males failed to spawn with wild females, yet wild males and F1 females were able to spawn successfully [35]. A final consideration that warrants further exploration are the effects of broodstock stocking densities, milt quality, sex ratios and social interactions, such as dominance hierarchy on spawning of Polyprion species-and handling stress during hormonal manipulations. These factors remain undescribed in hāpuku and have the potential to impair natural endocrine pathways and behaviors outlined above $[5,9,39]$.

When gametes were strip-spawned and fertilized in vitro, a fertilization rate of $84 \%$ was achieved (rates comparable to those observed in F0 broodstock) and normal embryonic development was completed to produce F2 offspring. However, egg quality quickly deteriorated over time as a second batch of eggs stripped from the same female $24 \mathrm{~h}$ later was overripe. These findings demonstrated (i) that F1 are capable of producing eggs of good quality, suggesting that external factors pre-spawning such as nutrition and husbandry stressors were less likely to be the cause of poor gamete quality; (ii) that in vitro fertilization can be used as a method to enhance selective breeding through single pair crosses in hāpuku; and (iii) that ovulated eggs are prone to overripening (within $24 \mathrm{~h}$ in this study). We believe the latter is a plausible explanation for the large quantities of unfertilized eggs communally produced over the two spawning seasons. This problem can be caused by inappropriate or lack of social cues and the sub-optimal timing (synchronization) of gamete release and fertilization between males and females. Consequently, females can spontaneously release overripe eggs into the water column [40]. Similar observations of large volumes of unfertilized eggs during spawning have recently been described in F0 wreckfish (Polyprion americanus) broodstock, where the authors also speculated that male contribution and spawning synchronization were likely factors causing this [41]. Further investigations to refine strip-spawning protocols could help identify the overripening period in hāpuku. However, a practical limitation is the repeated handling that this requires when dealing with large and valuable broodstock.

This study highlights the existence of reproductive dysfunctions in young captivity-produced F1 hāpuku. Sustained-release implants containing GnRHa at a target dose of $100 \mu \mathrm{g} / \mathrm{kg}^{-1}$ successfully induced communal spawning events in female F1 hāpuku that were otherwise reproductively dysfunctional and generally failed to ovulate on their own accord. Confirmed egg release from GnRHa-treated fish was first detected 12-15 days post-implantation and continued for up to 90 days 
post-implantation during the 2014 spawning season while ovulated eggs were not detected from blank-implanted fish. Lower target doses of GnRHa in females at $50 \mu \mathrm{g} / \mathrm{kg}^{-1}$ using the same type of implants were ineffective at inducing ovulation when implanted later in the season. Regardless of spawning season, no F2 offspring were produced during communal spawning in the two years of the study. However, gametes collected by strip-spawning and fertilized in vitro produced viable F2 offspring enabling the life-cycle of hāpuku to be completed in captivity for the first time, which was briefly reported by $[22,25]$ in reference to this study. Full-life cycle aquaculture is a critical milestone to achieve during the development of a new species as it removes the reliance on wild caught broodstock, improves biosecurity, reduces disease transmission risks and enables selective breeding of economically valuable traits (e.g., growth) $[2,42,43]$. The production of F1 and F2 as future breeding stock significantly enhances the likelihood of hāpuku becoming established as a new aquaculture product in New Zealand and globally.

\section{Materials and Methods}

\subsection{Experimental Design}

Spawning trials were conducted over two spawning seasons (2013 and 2014) when F1 were aged five and six years, respectively. All studies were completed in accordance with the Animal Welfare Act 1999 through New Zealand's National Institute of Water and Atmospheric Research Animal Ethics Committee.

During the first year, mixed-sex F1 hāpuku (brood year 2008; $n=80$ ๆand $67 o^{7}$; mean body weight $7.9 \pm 1.8 \mathrm{~kg}$; mean fork length $74 \pm 3.9 \mathrm{~cm}$ ) undergoing their maiden reproductive cycle were reared at NIWA's Northland Marine Research Centre, Ruakaka, New Zealand under two different temperature regimes for two years prior to and including the predicted spawning season, as detailed previously [23]. One temperature regime ( $n=4$ tanks; similar to that imposed on spontaneously spawning F0), annually cycled between cool temperatures in the winter months $\left(10.0-12.5^{\circ} \mathrm{C}\right)$ to warmer temperatures $\left(17^{\circ} \mathrm{C}\right)$ in the summer months, prior to being held at $13.5^{\circ} \mathrm{C}$ during the predicted spawning season (variable temperature, 'VT group'). The second temperature regime ( $n=3$ tanks) was maintained at a constant $17^{\circ} \mathrm{C}$ (constant temperature, 'CT group'). A constant temperature was selected on the basis of juvenile hāpuku growth performance [25] and its potential benefits for broodstock conditioning (e.g., ease of application and control) [23]. All fish were subjected to a simulated-natural photoperiod and fed to satiation three times a week on a moist pelleted broodstock diet (Broodmax, E. N. Hutchinson Ltd., Auckland, New Zealand). For identification and genotyping purposes, all fish were tagged with passive integrated transponder (PIT) tags (Trovan, UK) prior to experimentation.

Fish were left to spawn from August to October 2013 without any intervention. On 21 October 2013, when communal spawning was not evident, fish were anesthetized and the reproductive status of individuals was assessed as described previously [23].

\subsection{Trial: Collection of Gametes for Strip-Spawning and In Vitro Fertilization}

Females within the same tank in the late stages of vitellogenesis (Section 4.5) were administered either blank implants or implants containing $1 \mathrm{mg}$ GnRHa (target dose of $100 \mu \mathrm{g} / \mathrm{kg}^{-1}$; achieved dose $76-172 \mu \mathrm{g} / \mathrm{kg}^{-1}$ ). The implants, each weighing $30 \mathrm{mg}$ were made of a powdered cellulose (5\%) and cholesterol (95\%) matrix containing, or not (blank), $1 \mathrm{mg}$ of GnRHa as described previously [17,18]. The GnRHa (D-Ala6, des-Gly10-LHRH ethyl amide acetate; $>99 \%$ purity) was custom-synthesized by Biomatik (Cambridge, ON, Canada). Males (both spermiating and non-spermiating) were either administered blank implants or implants containing $0.25 \mathrm{mg}$ GnRHa (target dose of $25 \mu \mathrm{g} / \mathrm{kg}^{-1}$; achieved dose $26-47 \mu \mathrm{g} / \mathrm{kg}^{-1}$ ). Doses between $25 \mu \mathrm{g} / \mathrm{kg}^{-1}$ and $50 \mu \mathrm{g} / \mathrm{kg}^{-1}$ were selected for males on the basis of data available for other male marine broodstock [44-46]. Doses of GnRHa for females were adopted from a previous report, which were effective to induce spawning in captive wreckfish [47]. 
To avoid tank effects, blank- and GnRHa-implanted individuals were combined within each tank with the intention of genotyping fertilized eggs to determine the parental contribution for each spawn [2]. All tanks and egg collectors were monitored for egg release, and eggs were collected and assessed as described below (Section 4.7). Spawning was erratic and egg quality very poor, evident by their damaged or misshapen appearance and lack of fertilization (data not shown). Therefore, eight females from the VT group implanted in October (blank-implanted $n=4$; GnRHa-implanted $n=4$ ) and five females from the CT group (blank-implanted $n=2$; GnRHa-implanted $n=3$ ) were selected for in vitro fertilization (Section 4.6) on the basis of ovarian biopsies collected on 11 November 2013 (Table 1). Fish were subsequently allocated to new $20 \mathrm{~m}^{3}$ tanks according to their respective temperature regimes and co-housed with spermiating males (VT group $n=3 ; \mathrm{CT}$ group $n=2$ ) selected as sperm donors.

Selected GnRHa pre-treated females from both temperature groups received two IM injections of GnRHa (dose: $30 \mu \mathrm{g} / \mathrm{kg}^{-1}$ ) in saline, $24 \mathrm{~h}$ apart [47]; selected pre-treated controls were given two IM injections of saline only, $24 \mathrm{~h}$ apart. All fish were assessed for ovulation by stripping (Section 4.6) at $24 \mathrm{~h}$ intervals over a four-day period. Tanks and egg collectors were monitored for egg release (Section 4.7).

\subsection{Trial 2A: Effect of GnRHa Administration Using EVAc Implants on Communal Spawning}

In February 2014, early recrudescing F1 (the same fish used in 2013) were redistributed among the same seven experimental tanks to adjust tank biomasses and to evenly distribute individuals based on pedigree. For this trial, the CT regime was abandoned, as deemed ineffective [23] and all seven tanks were maintained under the same VT regime, photoperiod and husbandry conditions used in 2013.

Fish were left to spawn naturally from July to October 2014. As natural spawning was not evident for a second consecutive year, the reproductive status of fish was assessed through gonadal biopsy on 11 October 2014. Immature individuals were removed and tank biomasses adjusted. Individuals were also redistributed to avoid having related males and females in the same tank. The experimental design was refined, GnRHa-treatment tanks $(n=3)$ and blank-treatment tanks $(n=3)$ now being supplied by separate seawater filtration systems to avoid exchange of potential chemical cues (e.g., pheromones) between treatment and control tanks.

Late vitellogenic females were administered EVAc implants containing $1 \mathrm{mg}$ GnRHa $(n=21$; target dose of $100 \mu \mathrm{g} / \mathrm{kg}^{-1}$; achieved dose $79-139 \mu \mathrm{g} / \mathrm{kg}^{-1}$ ) or blank implants $(n=18)$. Males (both spermiating and non-spermiating) were administered blank implants $(n=23)$ or implants containing $0.5 \mathrm{mg}$ GnRHa $\left(n=19\right.$; target dose of $50 \mu \mathrm{g} / \mathrm{kg}^{-1}$; achieved dose $\left.49-76 \mu \mathrm{g} / \mathrm{kg}^{-1}\right)$. EVAc implants were constructed as previously outlined [13]. Variations in sample sizes/sex ratios reflect pedigree distribution to reduce inbreeding risks (no siblings in the same tank). Tanks were monitored for egg release over the following four weeks, and eggs were collected and assessed as described below (Section 4.7).

\subsection{Trial 2B: Effect of Different GnRHa Doses on Communal Spawning}

On 11 November 2014, 10 female control fish from Trial 2A (Section 4.3) were subdivided between two groups ( $n=5$ females/tank of $20 \mathrm{~m}^{3}$ ) and treated with GnRHa-containing EVAc implants, either at 'high dose' (1 mg GnRHa; achieved dose 95-145 $\left.\mu \mathrm{g} / \mathrm{kg}^{-1}\right)$ or at 'low dose' (0.5 mg GnRHa; achieved dose $\left.38-53 \mu \mathrm{g} / \mathrm{kg}^{-1}\right)$. Males in both tanks were administered implants containing $0.5 \mathrm{mg}$ GnRHa $(n=9$ per tank; achieved dose $48-86 \mu \mathrm{g} / \mathrm{kg}^{-1}$ ). Tanks were monitored for egg release, and eggs were collected and assessed as described below (Section 4.7).

\subsection{Anesthesia and Assessment of Reproductive Status}

Fish were mass-sedated in tanks $(0.01 \mathrm{~mL} / \mathrm{L}$ Aqui-S; Aqui-S New Zealand Ltd, Lower Hutt, New Zealand) after $48 \mathrm{~h}$ without food. Deep sedation of fish was achieved after transfer to a second anesthetic bath $(300 \mathrm{~L})$ containing $0.025 \mathrm{~mL} / \mathrm{L}$ Aqui-S. 
Prior to the collection of a gonadal biopsy by gonopore cannulation with a plastic cannula (PIPELLE ${ }^{\circledR}$ Mark II, C. C. D International) as previously described [23], the presence of free-flowing eggs was assessed by applying gentle pressure to the abdomen of the fish in a cranial-caudal direction. Retrieved ovarian tissue was added to Ringer's solution $(180 \mathrm{mM} \mathrm{NaCl} ; 4 \mathrm{mM} \mathrm{KCl} ; 1.5 \mathrm{mM} \mathrm{CaCl}$; $1.2 \mathrm{mM} \mathrm{MgSO} 4 ; 3 \mathrm{mM} \mathrm{NaH2PO} ; 12.5 \mathrm{NaHCO} 3$; $\mathrm{pH}$ 7.5) for oocyte measurement by light microscopy (Leica camera DFC420 and software version 2.8.0 Leica Microsystems Ltd., Zürich, Switzerland) as previously described [23]. Females considered for spawning induction were those found with late vitellogenic oocytes, defined as those with diameters $\geq 0.9 \mathrm{~mm}$ as previously described [23] (Figure 1a).

\subsection{Collection of Gametes for Strip-Spawning and In Vitro Fertilization}

At each $24 \mathrm{~h}$ interval, anesthetized females were assessed for ovulation by applying gentle pressure to the abdomen in a cranial-caudal direction as described above. Free-flowing ovulated eggs were collected into multiple small plastic containers, taking care to avoid contamination by urine, blood or feces during stripping. After assessing females for ovulation, an ovarian biopsy was collected from all females by gonopore cannulation and photographed to monitor changes in oocyte development.

Free-flowing milt was collected using $5 \mathrm{~mL}$ syringes from anesthetized males by applying gentle pressure to the abdomen as described above, again minimizing contamination by urine or feces by collecting milt in multiple small volumes. Freshly collected milt was stored at $4{ }^{\circ} \mathrm{C}$ prior to assessing sperm motility and selecting donor males. Assessment of sperm motility was achieved by activating sperm in full seawater at $\sim 13.5^{\circ} \mathrm{C}$ and observing motility by light microscopy. Males with estimated sperm motility of $\geq 90 \%$ were used to fertilize ovulated eggs.

\section{In Vitro Fertilization}

When ovulated eggs were successfully stripped from female fish, genetically unrelated males with an adequate quantity and quality of milt were selected and used for in vitro fertilization, a method adapted from that used for Atlantic cod (Gadus morhua) [48]. In brief, pooled milt from two or more males was combined with a small volume of sterilized seawater $\left(\sim 120 \mathrm{~mL}\right.$ at $\left.13.5^{\circ} \mathrm{C}\right)$ and immediately added to the eggs in a large bowl. Contents of the bowl were mixed gently by hand and the time of gamete activation was noted. After five minutes, a further 1-2 $\mathrm{L}$ of sterilized seawater was added to the bowl of gametes which were subjected to a second gentle mix. Thereafter, eggs were quality-scored as described in Section 4.7 .

\subsection{Egg Sampling}

Egg quality was assessed using the standard protocols developed for hāpuku eggs [49]; key parameters scored as indicators of egg quality included percentage of floating eggs (Section 4.7.1), fertilization percentage (Section 4.7.2) and hatching success (Section 4.7.4).

\subsubsection{Egg Collection and Assessment}

External and in-tank passive egg collectors were checked three times a day (between 8 and 9 am, at noon and between 4 and $5 \mathrm{pm}$ ) for spawned eggs from July to December in both years. When spawning had occurred, eggs were collected for assessment and/or incubation. The total volume, floating fractions (buoyancy) and sinking fractions were estimated in a measuring cylinder. Sinking fractions of eggs from each spawn were discarded prior to incubation and excluded from further sampling. Estimates of egg production data are presented as daily relative fecundity (number of eggs produced per $\mathrm{kg}^{-1}$ of mean body weight of the females in each tank for communal spawning events and number of eggs produced per $\mathrm{kg}^{-1}$ of body weight of individual females for strip-spawning). 


\subsubsection{Fertilization Rate and Fertilized Spawn Rate}

The fertilization rate for each spawn, defined as the number of fertilized eggs among 100 randomly selected floating eggs, was determined under a microscope. Fertilized eggs at a similar stage of development were considered to have originated from a single spawning event. Fertilized spawn rate of F1 hāpuku was defined as the number of spawns with fertilized eggs divided by the total number of spawns detected in the tank by the end of the season.

\subsubsection{Egg Incubation}

Floating eggs considered suitable for incubation were disinfected for $15 \mathrm{~min}$ with Chloramine-T (0.5 ppm) and rinsed with UV-sterilized seawater before being added to mesh baskets partially submerged in $400 \mathrm{~L}$ upwelling conical incubators or to the conical incubators themselves if egg volumes were sufficient (floating egg volume $>500 \mathrm{~mL}$ ). Eggs and developing larvae were kept in the incubators up to $10 \mathrm{dph}$ prior to transfer to larval rearing tanks for first feeding with live enriched rotifers as per [22].

\subsubsection{Hatching Estimates}

Hatching rates were estimated by placing freshly-fertilized eggs collected on the day in modified 24-well microtiter plates (two replicate plates) with one egg per well. These modified plates had holes drilled in the base which were covered with $500 \mu \mathrm{m}$ mesh to enable exchange of oxygenated water for the developing eggs. Microtiter plates were partially submerged within the incubators containing the bulk of the eggs from each corresponding spawn. Hatching rates were defined as the number of hatched larvae in the plates after 6 days divided by the number of eggs incubated.

\subsection{Genotyping (2014 Spawning Season Only)}

If egg volumes were sufficient, a sample of at least 60 fertilized eggs at the gastrula stage or later was collected from the floating egg fraction of each batch and preserved in $100 \%$ ethanol. Parentage analysis of the preserved embryos was performed by GenomNZ (Dunedin, New Zealand) [2]. Ideally, 30 eggs per batch were genotyped for parentage assignment. However, not all batches yielded this number of successfully genotyped eggs; in some cases, the genotyping did not work due to poor egg and embryo quality, or ambiguous parentage assignments.

\subsection{Larval and Juvenile Rearing}

Sequential changes in embryonic development were photographed (Figure 2) at regular intervals under a dissecting microscope (Leica camera DFC420 and software version 2.8.0 Leica Microsystems Ltd., Zürich, Switzerland) from $\sim 3.5 \mathrm{~h}$ post-fertilization until 20 days post-hatching as previously outlined [23].

By 10 days post-fertilization, yolk-sac larvae were transferred to larval rearing tanks ( 5 or $10 \mathrm{~m}^{3}$ ) in the nursery, reared using a semi-static green water protocol as previously described [22], and transferred for grow-out. Survival rate of larvae at 28 days post-hatching was calculated as the proportion of larvae remaining out of the number transferred to the larval rearing tanks.

Author Contributions: Conceptualization, M.J.W., A.N.S., J.E.S., A.E. and P.M.L.; Data curation, M.J.W.; Formal analysis, M.J.W.; Funding acquisition, M.J.W. and J.E.S.; Investigation, M.J.W. and G.W.I.; Resources, J.E.S., A.E., Y.Z. and P.M.L.; Supervision, A.N.S., J.E.S., A.E. and P.M.L.; Writing一original draft, M.J.W.; Writing一review \& editing, A.N.S., J.E.S., A.E., Y.Z. and P.M.L.

Funding: This research was supported by NIWA's Research Aquaculture Program 3 (2013/2014; 2014/15 SCI) funding. A University of Otago Māori Doctoral Scholarship and the Ngā Pae o te Māramatanga Doctoral Bridging Grant (17DBG02) to M.J.W. also supported this research.

Acknowledgments: We would like to acknowledge the contribution by the technical staff at New Zealand's National Institute of Water and Atmospheric Research (NIWA) for their roles in fish husbandry and for their assistance with sampling. 
Conflicts of Interest: The authors declare no conflict of interest.

\section{References}

1. Castro, L.I.; Alvarez-Lajonchère, L.; García-Aguilar, N.; de la Parra, M.I.A.; Rodríguez-lbarra, L.E. Generation cycle closure of the spotted rose snapper, Lutjanus guttatus, in captivity. Rev. Biol. Mar. Oceanog. 2012, 47, 333-337. [CrossRef]

2. Symonds, J.E.; Walker, S.P.; van de Ven, I.; Marchant, A.; Irvine, G.; Pether, S.; Gublin, Y.; Bruce, M.; Anderson, R.M.; McEwan, K.M. Developing broodstock resources for farmed marine fish. Proc. N. Z. Soc. Anim. Prod. 2012, 72, 222-226.

3. Camara, M.D.; Symonds, J.E. Genetic improvement of New Zealand aquaculture species: Programmes, progress and prospects. N. Z. J. Mar. Freshw. Res. 2014, 48, 466-491. [CrossRef]

4. Migaud, H.; Bell, G.; Cabrita, E.; McAndrew, B.; Davie, A.; Bobe, J.; Herráez, M.P.; Carrillo, M. Gamete quality and broodstock management in temperate fish. Rev. Aquacult. 2013, 5, 194-223. [CrossRef]

5. Mylonas, C.C.; Zohar, Y. Use of GnRHa-delivery systems for the control of reproduction in fish. Rev. Fish Biol. Fish. 2001, 10, 463-491. [CrossRef]

6. Zohar, Y.; Mylonas, C.C. Endocrine manipulations of spawning in cultured fish: From hormones to genes. Aquaculture 2001, 197, 99-136. [CrossRef]

7. Mañanós, E.; Carrillo, M.; Sorbera, L.A.; Mylonas, C.C.; Asturiano, J.F.; Bayarri, M.J.; Zohar, Y. Luteinizing hormone and sexual steroid plasma levels after treatment of European sea bass with sustained-release delivery systems for gonadotropin-releasing hormone analogue. J. Fish Biol. 2002, 60, 328-339.

8. Schreck, C.B.; Contreras-Sanchez, W.; Fitzpatrick, M.S. Effects of stress on fish reproduction, gamete quality, and progeny. Aquaculture 2001, 197, 3-24. [CrossRef]

9. Mylonas, C.C.; Fostier, A.; Zanuy, S. Broodstock management and hormonal manipulations of fish reproduction. Gen. Comp. Endocrinol. 2010, 165, 516-534. [CrossRef]

10. Levavi-Sivan, B.; Bogerd, J.; Mañanós, E.L.; Gómez, A.; Lareyre, J.J. Perspectives on fish gonadotropins and their receptors. Gen. Comp. Endocrinol. 2010, 165, 412-437. [CrossRef]

11. Lubzens, E.; Young, G.; Bobe, J.; Cerdá, J. Oogenesis in teleosts: How fish eggs are formed. Gen. Comp. Endocrinol. 2010, 165, 367-389. [CrossRef]

12. Zohar, Y.; Muñoz-Cueto, J.A.; Elizur, A.; Kah, O. Neuroendocrinology of reproduction in teleost fish. Gen. Comp. Endocrinol. 2010, 165, 438-455. [CrossRef]

13. Mylonas, C.C.; Bridges, C.; Gordin, H.; Ríos, A.B.; García, A.; De La Gándara, F.; Fauvel, C.; Suquet, M.; Medina, A.; Papadaki, M.; et al. Preparation and administration of gonadotropin-releasing hormone agonist (GnRHa) implants for the artificial control of reproductive maturation in captive-reared Atlantic bluefin tuna (Thunnus thynnus thynnus). Rev. Fish Sci. 2007, 15, 183-210. [CrossRef]

14. Fernández-Palacios, H.; Schuchardt, D.; Roo, J.; Hernádez-Cruz, C.; Izquierdo, M. Spawn quality and GnRHa induction efficiency in longfin yellowtail (Seriola rivoliana) broodstock kept in captivity. Aquaculture 2015, 435, 167-172. [CrossRef]

15. Mylonas, C.C.; Salone, S.; Biglino, T.; de Mello, P.H.; Fakriadis, I.; Sigelaki, I.; Duncan, N. Enhancement of oogenesis/spermatogenesis in meagre Argyrosomus regius using a combination of temperature control and GnRHa treatments. Aquaculture 2016, 464, 323-330. [CrossRef]

16. Amezawa, K.; Yazawa, R.; Takeuchi, Y.; Yoshizaki, G. Spawning induction of blue mackerel Scomber australasicus and Eastern little tuna Euthynnus affinis by oral administration of a crude gonadotropin-releasing hormone analogue. Fish. Sci. 2018, 84, 495-504. [CrossRef]

17. Crim, L.W.; Sherwood, N.M.; Wilson, C.E. Sustained hormone release. II. Effectiveness of LHRH analog (LHRHa) administration by either single time injection or cholesterol pellet implantation on plasma gonadotropin levels in a bioassay model fish, the juvenile rainbow trout. Aquaculture 1988, 74, 87-95. [CrossRef]

18. Lokman, P.M.; Wylie, M.J.; Downes, M.; Di Biase, A.; Damsteegt, E.L. Artificial induction of maturation in female silver eels, Anguilla australis: The benefits of androgen pre-treatment. Aquaculture 2015, 437, 111-119. [CrossRef] 
19. Forniés, M.A.; Mañanós, E.; Carrillo, M.; Rocha, A.; Laureau, S.; Mylonas, C.C.; Zohar, Y.; Zanuy, S. Spawning induction of individual European sea bass females (Dicentrarchus labrax) using different GnRHa-delivery systems. Aquaculture 2001, 202, 221-234. [CrossRef]

20. Lee, C.S.; Tamaru, C.S.; Kelley, C.D. Technique for making chronic-release LHRH-A and $17 \alpha$-methyltestosterone pellets for intramuscular implantation in fishes. Aquaculture 1986, 59, 161-168. [CrossRef]

21. Mylonas, C.C.; Woods, L.C.; Thomas, P.; Zohar, Y. Endocrine profiles of female striped bass (Morone saxatilis) in captivity, during post-vitellogenesis and induction of final oocyte maturation via controlled release GnRHa-delivery systems. Gen. Comp. Endocrinol. 1998, 110, 276-289. [CrossRef]

22. Symonds, J.E.; Walker, S.P.; Pether, S.; Gublin, Y.; McQueen, D.; King, A.; Irvine, G.W.; Setiawan, A.N.; Forsythe, J.A.; Bruce, M. Developing yellowtail kingfish (Seriola lalandi) and hāpuku (Polyprion oxygeneios) for New Zealand aquaculture. N. Z. J. Mar. Freshw. Res. 2014, 48, 371-384. [CrossRef]

23. Wylie, M.J.; Setiawan, A.N.; Irvine, G.W.; Symonds, J.E.; Elizur, A.; Dos Santos, M.; Lokman, P.M. Ovarian development of captive F1 wreckfish (hāpuku) Polyprion oxygeneios under constant and varying temperature regimes-Implications for broodstock management. Gen. Comp. Endocrinol. 2018, 257, 86-96. [CrossRef]

24. Anderson, S.A.; Salinas, I.; Walker, S.P.; Gublin, Y.; Pether, S.; Kohn, Y.Y.; Symonds, J.E. Early development of New Zealand hapuku Polyprion oxygeneios eggs and larvae. J. Fish Biol. 2012, 80, 555-571. [CrossRef]

25. Tromp, J.J.; Jones, P.L.; Symonds, J.E.; Walker, S.P.; Pope, A.; Pether, S.M.; Afonso, L.O. Effects of commercial diets and temperature on the growth performance and stress response of hāpuku (Polyprion oxygeneios). Aquaculture 2016, 452, 128-133. [CrossRef]

26. Nagahama, Y.; Yamashita, M. Regulation of oocyte maturation in fish. Dev. Growth Differ. 2008, 50, 195-219. [CrossRef]

27. Zohar, Y.; Pagelson, G.; Tosky, M. Daily changes in reproductive hormone levels in the female gilthead seabream Sparus aurata at the spawning period. In Reproduction in Fish: Basic and Applied Aspects of Endocrinology and Genetics; Zohar, Y., Breton, B., Eds.; INRA Press: Paris, France, 1988; pp. 119-125.

28. Rasines, I.; Gómez, M.; Martín, I.; Rodríguez, C.; Mañanós, E.; Chereguini, O. Artificial fertilization of Senegalese sole (Solea senegalensis): Hormone therapy administration methods, timing of ovulation and viability of eggs retained in the ovarian cavity. Aquaculture 2012, 326, 129-135. [CrossRef]

29. Francis, M.P.; Mulligan, K.P.; Davies, N.M.; Beentjes, M.P. Age and growth estimates for New Zealand hāpuku, Polyprion oxygeneios. Fish. Bull. 1999, 97, 227-242.

30. Steven, C.; Gothilf, Y.; Holland, M.C.H.; Stubblefield, J.; Mylonas, C.C.; Zohar, Y. Differential expression of the three GnRH genes in wild and captive striped bass, Morone saxatilis, in response to natural and hormonally induced maturation. In Reproductive Physiology of Fish; Norberg, B., Kjesbu, O.S., Taranger, G.L., Andersson, E., Eds.; University of Bergen: Bergen, Norway, 2000; p. 66.

31. Newman, D.M.; Jones, P.L.; Ingram, B.A. Age-related changes in ovarian characteristics, plasma sex steroids and fertility during pubertal development in captive female Murray cod Maccullochella peelii peelii. Comp. Biochem. Physiol. A Mol. Integr. Physiol. 2008, 150, 444-451. [CrossRef]

32. Lastein, S.; Gregersen, F.; Døving, K.B. Seasonal variations in olfactory sensory neurons-Fish sensitivity to sex pheromones explained? Chem. Senses 2008, 33, 119-123.

33. Munakata, A.; Kobayashi, M. Endocrine control of sexual behavior in teleost fish. Gen. Comp. Endocrinol. 2010, 165, 456-468. [CrossRef]

34. Rekwot, P.I.; Ogwu, D.; Oyedipe, E.O.; Sekoni, V.O. The role of pheromones and biostimulation in animal reproduction. Anim. Reprod. Sci. 2001, 65, 157-170. [CrossRef]

35. Carazo, I.; Martin, I.; Hubbard, P.; Chereguini, O.; Maatanas, E.; Canário, A.; Duncan, N. Reproductive behaviour, the absence of reproductive behaviour in cultured (G1 generation) and chemical communication in the Senegalese sole (Solea senegalensis). Indian J. Sci. Technol. 2011, 4, 96-97.

36. Meiri, I.; Gothilf, Y.; Zohar, Y.; Elizur, A. Physiological changes in the spawning gilthead seabream Sparus aurata, succeeding the removal of males. J. Exp. Zool. 2002, 292, 555-564. [CrossRef]

37. Soyano, K.; Izumida, D.; Nakachi, M.; Murata, R.; Nakamura, M. The final oocyte maturation regulated by the pheromone released from male in the honeycomb grouper. In Proceedings of the 7th International Symposium on Fish Endocrinology, Buenos Aries, Argentina, 3-6 September 2012.

38. Rainwater, F.L. Courtship and reproductive behavior of the Siamese fighting fish Betta splendens Regan (Pisces, Belontiidae). Proc. OK Acad. Sci. 1967, 47, 98-114. 
39. Pankhurst, N.W. Hormones and reproductive behaviour in male damselfish. Bull. Mar. Sci. 1995, 57, 569-581.

40. Mohagheghi Samarin, A.; Policar, T.; Lahnsteiner, F. Fish oocyte aging and its effects on egg quality. Rev. Fish. Sci. Aquac. 2015, 23, 302-314. [CrossRef]

41. Papadaki, M.; Peleteiro, J.; Alvarez-Blázquez, B.; Rodríguez Villanueva, J.; Linares, F.; Vilar, A.; Pérez Rial, E.; Lluch, N.; Fakriadis, I.; Sigelaki, I.; et al. Description of the annual reproductive cycle of wreckfish Polyprion americanus in captivity. Fishes 2018, 3, 43. [CrossRef]

42. Whatmore, P.; Nguyen, N.H.; Miller, A.; Lamont, R.; Powell, D.; D’Antignana, T.; Bubner, E.; Elizur, A.; Knibb, W. Genetic parameters for economically important traits in yellowtail kingfish Seriola lalandi. Aquaculture 2013, 400, 77-84. [CrossRef]

43. Bobe, J. Egg quality in fish: Present and future challenges. Anim. Front. 2015, 5, 66-72. [CrossRef]

44. Mylonas, C.C.; Scott, A.P.; Vermeirssen, E.L.; Zohar, Y. Changes in plasma gonadotropin II and sex steroid hormones, and sperm production of striped bass after treatment with controlled-release gonadotropin-releasing hormone agonist-delivery systems. Biol. Reprod. 1997, 57, 669-675. [CrossRef]

45. Rainis, S.; Mylonas, C.C.; Kyriakou, Y.; Divanach, P. Enhancement of spermiation in European sea bass (Dicentrarchus labrax) at the end of the reproductive season using GnRHa implants. Aquaculture 2003, 219, 873-890. [CrossRef]

46. Vermeirssen, E.L.; de Quero, C.M.; Shields, R.J.; Norberg, B.; Kime, D.E.; Scott, A.P. Fertility and motility of sperm from Atlantic halibut (Hippoglossus hippoglossus) in relation to dose and timing of gonadotrophin-releasing hormone agonist implant. Aquaculture 2004, 230, 547-567. [CrossRef]

47. Fauvel, C.; Suquet, M.; Severe, A.; Mylonas, C.C.; Papandroulakis, N. Slow-release GnRHa treatment prevented atresia during vitellogenesis and induced ovulation of captive wreckfish (Polyprion americanus). Cybium 2008, 32, 191.

48. Butts, I.A.; Trippel, E.A.; Litvak, M.K. The effect of sperm to egg ratio and gamete contact time of fertilisation success in Atlantic Cod Gadus morhuna L. Aquaculture 2009, 286, 89-94. [CrossRef]

49. Kohn, Y.Y.; Symonds, J.E. Evaluation of egg quality parameters as predictors of hatching success and early larval survival in hāpuku (Polyprion oxygeneios). Aquaculture 2012, 342, 42-47. [CrossRef]

(C) 2019 by the authors. Licensee MDPI, Basel, Switzerland. This article is an open access article distributed under the terms and conditions of the Creative Commons Attribution (CC BY) license (http://creativecommons.org/licenses/by/4.0/). 